\title{
Role of Fluxes in the Synthesis and Luminescence Properties of $\mathrm{Ba}_{3} \mathrm{Si}_{6} \mathrm{O}_{12} \mathrm{~N}_{2}: \mathrm{Eu}^{2+}$ Oxynitride Phosphors by Microwave Sintering
}

\author{
HAN Bin ${ }^{1,2}$, WANG Yi-Fei ${ }^{2}$, LIU Qian ${ }^{3}$, HUANG Qing ${ }^{2}$
}

(1. Institute of Materials, Shanghai University, Shanghai 200072, China; 2. Engineering Laboratory of Specialty Fibers and Nuclear Energy Materials, Ningbo Institute of Materials Engineering and Technology, Chinese Academy of Sciences, Ningbo 315201, China; 3. State Key Laboratory of High Performance Ceramics and Superfine Microstructure, Shanghai Institute of Ceramics, Chinese Academy of Sciences, Shanghai 200050, China)

\begin{abstract}
Eu}^{2+}$ activated $\mathrm{Ba}_{3} \mathrm{Si}_{6} \mathrm{O}_{12} \mathrm{~N}_{2}$ oxynitride green phosphors were synthesized by microwave sintering method with the aid of fluxes, namely $\mathrm{BaCl}_{2}, \mathrm{H}_{3} \mathrm{BO}_{3}, \mathrm{KF}$, and $\mathrm{NH}_{4} \mathrm{~F}$. We employed a combination of X-ray diffraction, photoluminescence spectra and scanning electron microscopy measurements, in conjunction with detailed quantum efficiency $(\mathrm{QE})$, life time and thermal quenching studies of luminescence properties to understand the origins of the improved luminescence properties. The results showed that the photoluminescence intensity of the phosphors was increased obviously by using varied fluxes and the intensity rise was recorded in order of fluxes as following: $\mathrm{H}_{3} \mathrm{BO}_{3}>$ $\mathrm{KF}>\mathrm{BaCl}_{2}>$ no flux $>\mathrm{NH}_{4} \mathrm{~F}$. The maximum emission intensity of the $\mathrm{Ba}_{3} \mathrm{Si}_{6} \mathrm{O}_{12} \mathrm{~N}_{2}: \mathrm{Eu}^{2+}$ phosphor was achieved at containing $1.0 \mathrm{wt} \% \mathrm{H}_{3} \mathrm{BO}_{3}$, due to the high crystallinity, narrow particle-size distribution and smooth surface, which showed low thermal quenching, shorter life time and increased external quantum efficiency, compared with that of the sample with other fluxes or without flux.
\end{abstract}

Key words: oxynitride phosphor; flux; microwave sintering; quantum efficiency

White light-emitting diodes (W-LEDs) have attracted significant attention over the past few years as a potential replacement for incandescent and fluorescent light sources. Normally, the common approach for fabricating the W-LEDs is to combine an InGaN blue chip with a yellow-emitting phosphor, $\mathrm{Y}_{3} \mathrm{Al}_{5} \mathrm{O}_{12}: \mathrm{Ce}^{3+}$. Yet $\mathrm{Y}_{3} \mathrm{Al}_{5} \mathrm{O}_{12}: \mathrm{Ce}^{3+}$ is not ideal as it suffers from poor color rendition because of weak luminescence in the red spectral region ${ }^{[1-2]}$. As the phosphor considered as one of the pivotal and technological parts in W-LEDs, photoluminescence (PL) properties of the phosphor can determine the performance of the LED device ${ }^{[3]}$. So, a wide variety of nitride or oxynitride phosphors have been developed recently for use in W-LEDs ${ }^{[4-8]}$, such as Ca- $\alpha-\mathrm{SiAlON}: \mathrm{Ce}^{3+[4]}, \mathrm{Ca}-\alpha-\mathrm{SiAlON}$ : $\mathrm{Eu}^{2+[5]}, \beta-\mathrm{SiAlON}: \mathrm{Eu}^{2+[6]}, \mathrm{M}_{2} \mathrm{Si}_{5} \mathrm{~N}_{8}: \mathrm{Eu}^{2+}(\mathrm{M}=\mathrm{Ca}, \mathrm{Sr}, \mathrm{Ba})^{[7]}$, and $\mathrm{CaAlSiN}_{3}: \mathrm{Eu}^{2+[8]}$, owing to the advantages of these rare-earth doped nitride phosphors, including strong absorption from the ultraviolet (UV) to the blue region, high quantum efficiency, and excellent thermal quenching characteristics compared to oxide and sulfide-based phosphors, they are vastly used as efficient conversion phosphors for W-LEDs. Among the phosphors, green-emitting phosphors have gained increasing attention because of the broad band emission in the greenlight wavelength range, which significantly enhances the color rendering index of W-LEDs. Recently, $\mathrm{Ba}_{3} \mathrm{Si}_{6} \mathrm{O}_{12} \mathrm{~N}_{2}: \mathrm{Eu}^{2+}$ has attracted considerable interest due to its high efficiency, excellent thermal properties, and chemical stability ${ }^{[9-13]}$. However, a pure phase of $\mathrm{Ba}_{3} \mathrm{Si}_{6} \mathrm{O}_{12} \mathrm{~N}_{2}: \mathrm{Eu}$ is hardly obtained, due to the low chemical reactivity of starting powders $\mathrm{Si}_{3} \mathrm{~N}_{4}{ }^{[4]}$.

In recent years, microwave sintering is a relatively new technique. The advantages of high temperature microwave processing have been demonstrated in such fields as sintering and joining of ceramic materials, inorganic synthesis, development of composite materials ${ }^{[14]}$, which attracts the attention of many researchers due to its advantages over the conventional sintering, such as rapid heating rate, decreased sintering temperature, improved physical and mechanical properties, high purity, and lower environ-

Received date: 2015-12-01; Modified date: 2015-12-23

Foundation item: Zhejiang Provincial Natural Science Foundation of China (R12E020005, LQ14E020007); Natural Science Foundation of Ningbo (2013A610027); State Key Laboratory of High Performance Ceramics and Superfine Microstructure, Chinese Academy of Sciences (SKL201307SIC); Research Fund for the Postdoctoral Advanced Program of Zhejiang Province (BSH1301022); Ningbo International Cooperation (2015D10009)

Biography: HAN Bin(1991-), male, candidate of Master degree. E-mail: hanbin@nimte.ac.cn

Corresponding author: WANG Yi-Fei, assistant professor. E-mail: wangyf@nimte.ac.cn; HUANG Qing, professor. E-mail: huangqing@nimte.ac.cn 
mental hazards ${ }^{[15-18]}$. For the $\mathrm{Si}_{3} \mathrm{~N}_{4}$ systems, microwave heating has been observed to accelerate or enhance diffusion processes, such as sintering and grain growth ${ }^{[18]}$. In our previous report, $\mathrm{Eu}^{2+}$ - activated $\mathrm{Ba}_{3} \mathrm{Si}_{6} \mathrm{O}_{12} \mathrm{~N}_{2}$ phosphors were synthesized by both solid state reaction and microwave sintering methods. Comparatively, microwave sintering method could significantly reduce the firing time for the $\mathrm{Ba}_{3} \mathrm{Si}_{6} \mathrm{O}_{12} \mathrm{~N}_{2}$ : Eu ${ }^{2+}$ phosphors. The highest PL intensity was obtained in the $\mathrm{Ba}_{2.8} \mathrm{Si}_{6} \mathrm{O}_{12} \mathrm{~N}_{2}: 0.2 \mathrm{Eu}^{2+}$ phosphor prepared by microwave sintering method at $1275^{\circ} \mathrm{C}$ for $4 \mathrm{~h}$ using a $0.8 \mathrm{Si}_{3} \mathrm{~N}_{4}$ rich composition ${ }^{[19]}$. There are several important factors to affect the luminescence properties of the phosphor, such as particle shape, surface, size, crystallinity and composition homogeneity. In general, the particles with a uniform shape and a smooth surface have better photoluminescence intensity than that of the particles with an irregular shape and a rough surface ${ }^{[20]}$. Adding flux in the raw material has been used in order to control these factors in various synthetic processes. Since the flux materials, such as oxides, halides, fluorides, and carbonates, usually have low melting points, they behave like a liquid phase to facilitate the particle growth. Therefore, the flux method has potential advantages such as the mass productivity and the ability to obtain the fine particle morphology as well as the control of the particle size of products, and so on. There are reports which have postulated that the use of fluxes can improve the photoluminescence properties of phosphors, such as $\mathrm{NH}_{4} \mathrm{Cl}, \mathrm{SrCl}_{2}, \mathrm{SrF}_{2}$, and $\mathrm{AlF}_{3}$ for $\mathrm{SrSi}_{2} \mathrm{O}_{2} \mathrm{~N}_{2}: \mathrm{Eu}^{2+}$ green phosphors ${ }^{[3]}, \mathrm{NaCl}$ for $\mathrm{KSrPO}_{4}: \mathrm{Eu}^{2+}$ blue phosphors ${ }^{[21]}, \mathrm{H}_{3} \mathrm{BO}_{3}$ for $\mathrm{CaAl}_{2} \mathrm{O}_{4}: \mathrm{Eu}^{2+}$, $\mathrm{Nd}^{3+}$ blue phosphors ${ }^{[22]}, \mathrm{BaF}_{2}, \mathrm{CaF}_{2}, \mathrm{AlF}_{3}, \mathrm{H}_{3} \mathrm{BO}_{3}, \mathrm{NH}_{4} \mathrm{Cl}$, and $\mathrm{NH}_{4} \mathrm{~F}$ for $\mathrm{Y}_{2} \mathrm{O}_{3}: \mathrm{Eu}^{3+}$ red phosphors ${ }^{[23]}, \mathrm{NaF}, \mathrm{BaF}_{2}$, $\mathrm{H}_{3} \mathrm{BO}_{3}$, and $\mathrm{NH}_{4} \mathrm{Cl}$ for $\mathrm{Lu}_{3-\mathrm{x}} \mathrm{Al}_{5} \mathrm{O}_{12}: x \mathrm{Ce}^{3+}$ green phosphors ${ }^{[24]}$, and $\mathrm{BaF}_{2}$ for $\mathrm{CaAlSiN}_{3}: \mathrm{Eu}^{2+}$ red phosphors ${ }^{[8]}$. There are too many investigation for the preparation and structure of the $\mathrm{Ba}_{3} \mathrm{Si}_{6} \mathrm{O}_{12} \mathrm{~N}_{2}: \mathrm{Eu}^{2+}$ phosphors ${ }^{[9-13]}$, however, the influences of fluxes on its luminescence is too limited, to the best of our knowledge, there are no works that systematically report on the effect of fluxes in the case of $\mathrm{Ba}_{3} \mathrm{Si}_{6} \mathrm{O}_{12} \mathrm{~N}_{2}: \mathrm{Eu}^{2+}$ green phosphors. Further more, the selection of an appropriate flux material and understanding of flux effect on the optical properties may differ from one phosphor to another.

In present work, different fluxes $\left(\mathrm{BaCl}_{2}, \mathrm{H}_{3} \mathrm{BO}_{3}, \mathrm{KF}\right.$, and $\mathrm{NH}_{4} \mathrm{~F}$ ) were added when synthesizing $\mathrm{Ba}_{3} \mathrm{Si}_{6} \mathrm{O}_{12} \mathrm{~N}_{2}: \mathrm{Eu}^{2+}$ phosphors by microwave sintering method and the effects of these fluxes on the phase formation, morphology, particle size, and PL intensity of the $\mathrm{Ba}_{3} \mathrm{Si}_{6} \mathrm{O}_{12} \mathrm{~N}_{2}$ : $\mathrm{Eu}^{2+}$ phosphors were investigated. Thermal quenching, life time and quantum efficiency $(\mathrm{QE})$ of the $\mathrm{Ba}_{3} \mathrm{Si}_{6} \mathrm{O}_{12} \mathrm{~N}_{2}: \mathrm{Eu}^{2+}$ phos- phors with various kinds of fluxes were also measureol. We concentrate on finding the appropriate flux material which can improve the optical performance for $\mathrm{Ba}_{3} \mathrm{Si}_{6} \mathrm{O}_{12}$ $\mathrm{N}_{2}: \mathrm{Eu}^{2+}$ green phosphors, which is an important factor from the perspective of applicability.

\section{Experimental}

\subsection{Preparation}

A series of $\mathrm{Ba}_{2.8} \mathrm{Si}_{6} \mathrm{O}_{12} \mathrm{~N}_{2}: 0.2 \mathrm{Eu}^{2+}$ samples added with fluxes of $0.5 \mathrm{wt} \%-5 \mathrm{wt} \%$ of $\mathrm{BaCl}_{2}, \mathrm{H}_{3} \mathrm{BO}_{3}, \mathrm{KF}$, and $\mathrm{NH}_{4} \mathrm{~F}$ were synthesized by microwave sintering method. Stoichiometric mixtures of $\mathrm{Eu}_{2} \mathrm{O}_{3}$ (Sinopharm Chemical Reagent Co., Ltd, $4 \mathrm{~N}$ ), $\alpha-\mathrm{Si}_{3} \mathrm{~N}_{4}$ (UBE, SN-E10), $\mathrm{BaCO}_{3}$ (Aladdin, AR), $\mathrm{SiO}_{2}$ (Aladdin, 99.99\%), $\mathrm{BaCl}_{2}$ (Sinopharm Chemical Reagent Co., Ltd, AR), KF (Sinopharm Chemical Reagent Co., Ltd, 4N), $\mathrm{NH}_{4} \mathrm{~F}$ (Sinopharm Chemical Reagent Co., Ltd, AR) and $\mathrm{H}_{3} \mathrm{BO}_{3}$ (Sinopharm Chemical Reagent Co., Ltd, GR) were weighted out and mixed in a mortar by hand and then packed into the BN crucibles. For the microwave sintering technique, firstly, we put the filled $\mathrm{BN}$ crucibles into an attemperator with heating assistant materials, then put the attemperator into microwave reaction furnace, and finally sintered the powder samples under a reducing atmosphere $\left(15 \% \mathrm{H}_{2} / \mathrm{N}_{2}\right)$ from $1100^{\circ} \mathrm{C}$ to $1300^{\circ} \mathrm{C}$ for $4 \mathrm{~h}$.

\subsection{Characterization}

The crystalline phase of the samples was analyzed by an X-ray powder diffraction (XRD, Advance D8, Bruker, Karlsruhe, German) using the $\mathrm{Cu} \mathrm{K} \alpha, \lambda=0.15418 \mathrm{~nm}$, operating at $40 \mathrm{kV}$ and $40 \mathrm{~mA}$ in the $2 \theta$ range of $10^{\circ}-60^{\circ}$ with a step size of $0.02^{\circ}$ and $0.2 \mathrm{~s}$ per step. PL spectra were measured at room temperature using a fluorescent spectrophotometer (F-4600, Hitachi Ltd., Tokyo, Japan) with a $150 \mathrm{~W}$ Xe lamp as an excitation source at room temperature. The morphology of the samples was observed by scanning electron microscope (FE-SEM, S-4800, Hitachi, Japan). The particle size was analyzed on a particle size analyzer (S3500-special, Microtrac, USA). The absorption, quantum efficiency and thermal quenching of the prepared phosphor were measured using a QE-2100 (Otsuka Electronics Co., Ltd., Japan) and the reflection spectrum of $\mathrm{BaSO}_{4}$ white standard was used for calibration. The decay curves were obtained by Fluorolog spectrofluorometer (FL3-111, Horiba, Japan) using a Nano LED (pulse duration $=1.2 \mathrm{~ns}, \lambda_{\mathrm{em}}=457 \mathrm{~nm}$ ) as the excitation source. The thermal quenching measurements were conducted under the excitation of $455 \mathrm{~nm}$ from $25^{\circ} \mathrm{C}$ to $300^{\circ} \mathrm{C}$ at an interval of $50^{\circ} \mathrm{C}$ with holding time of $10 \mathrm{~min}$ at each temperature. The CIE chromaticity coordinates at 
various temperatures were given by the QE-2100 system. Photographs of the samples under $365 \mathrm{~nm}$ UV light were taken by the digital camera.

\section{Results and discussion}

\subsection{Properties of $\mathrm{Ba}_{2.8} \mathrm{Si}_{6} \mathrm{O}_{12} \mathrm{~N}_{2}: \mathrm{Eu}^{2+}$ synthe- sized with different fluxes}

The influence of temperature on the emission intensity of the $\mathrm{Ba}_{3} \mathrm{Si}_{6} \mathrm{O}_{12} \mathrm{~N}_{2}: \mathrm{Eu}^{2+}$ phosphors with $1 \mathrm{wt} \%$ adding amount of different fluxes $\left(\mathrm{BaCl}_{2}, \mathrm{H}_{3} \mathrm{BO}_{3}, \mathrm{KF}, \mathrm{NH}_{4} \mathrm{~F}\right)$ firing at various temperatures are presented in Fig. 1(a). In all case, the emission intensities of all the samples increase firstly, and then fall down after the emission intensity reaches the maximum value. For the phosphors without flux and with $\mathrm{BaCl}_{2}, \mathrm{H}_{3} \mathrm{BO}_{3}, \mathrm{KF}, \mathrm{NH}_{4} \mathrm{~F}$ fluxes, the optimal sintering temperatures seem to be $1250^{\circ} \mathrm{C}, 1200^{\circ} \mathrm{C}, 1250^{\circ} \mathrm{C}, 1200^{\circ} \mathrm{C}$ and $1150^{\circ} \mathrm{C}$, respectively, likely correspond to the temperature for obtaining highest crystallinity. Fig. 1(b) presents the XRD patterns of $\mathrm{Ba}_{2.8} \mathrm{Si}_{6} \mathrm{O}_{12} \mathrm{~N}_{2}: 0.2 \mathrm{Eu}^{2+}$ synthesized without flux and with $\mathrm{BaCl}_{2}, \mathrm{H}_{3} \mathrm{BO}_{3}, \mathrm{KF}, \mathrm{NH}_{4} \mathrm{~F}$ at the optimum temperature for each kind of the flux, indicating that the photoluminescence intensity of the phosphor is deeply affected by the crystallinity. Therefore, adding the flux could reduce the optimal sintered temperature and enhance the crystallinity, because fluxes melt at lower temperature than the solid state reaction temperature and serve as solvents for the reactants accelerating the reaction.

The influence of the content of fluxes on the crystalline structure and the emission intensity of the $\mathrm{Ba}_{3} \mathrm{Si}_{6} \mathrm{O}_{12} \mathrm{~N}_{2}: \mathrm{Eu}^{2+}$ phosphors will be investigated for further clarification (Fig. 2 and Fig. 3). Under the optimum temperature for each kind of the flux as shown in Fig. 1, the fluxes content was tested with an increased tendency from $0.5 \mathrm{wt} \%$ to $5 \mathrm{wt} \%$, however, the desired product of $\mathrm{Ba}_{3} \mathrm{Si}_{6} \mathrm{O}_{12} \mathrm{~N}_{2}: \mathrm{Eu}^{2+}$ was hardly obtained due to the agglomeration of phosphors

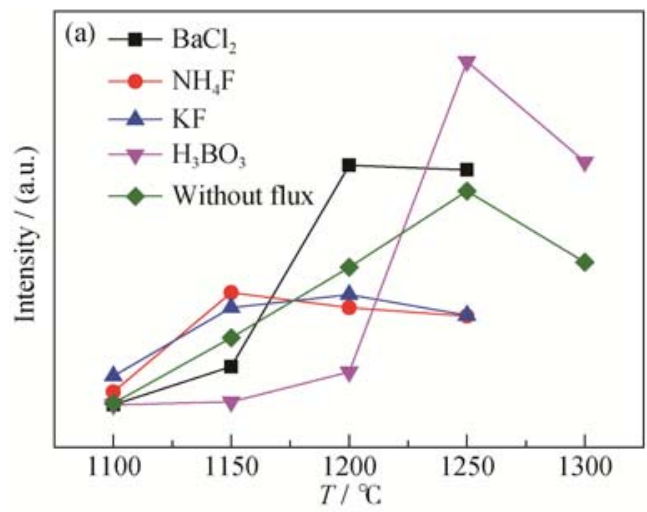

particles for the higher flux adding amounts above $2 \mathrm{wt} \%$ and $3 \mathrm{wt} \%$ for $\mathrm{KF}$ and $\mathrm{NH}_{4} \mathrm{~F}$, respectively. For the sample doped with $\mathrm{BaCl}_{2}$ flux (Fig. 2(a)), it seems that there is no perceptible influence of the flux amount on the crystalline structure of the $\mathrm{Ba}_{3} \mathrm{Si}_{6} \mathrm{O}_{12} \mathrm{~N}_{2}: \mathrm{Eu}^{2+}$ phosphors, and the obvious change is that the $\mathrm{BaSiO}_{3}$ impurity phase disappears, instead, $\mathrm{Ba}_{4} \mathrm{Si}_{6} \mathrm{O}_{16}$ emerges. In the case of $\mathrm{H}_{3} \mathrm{BO}_{3}$ flux (Fig. 2(b)), different from the case of $\mathrm{BaCl}_{2}$, more silicate $\mathrm{Ba}_{4} \mathrm{Si}_{6} \mathrm{O}_{16}$ phase are detected when the $\mathrm{H}_{3} \mathrm{BO}_{3}$ adding amount increases to $5 \mathrm{wt} \%$. For another flux, such as $\mathrm{KF}$ and $\mathrm{NH}_{4} \mathrm{~F}$, the weak diffraction peaks of impurities $\mathrm{BaSiO}_{3}$ phase are detected, as can be seen from Fig. 2(c) and (d). The above phenomenon may be due to the process of the phase formation of the $\mathrm{Ba}_{3} \mathrm{Si}_{6} \mathrm{O}_{12} \mathrm{~N}_{2}: \mathrm{Eu}^{2+}$ phosphors ${ }^{[19]}$.

The adding amounts of fluxes have a deep influence on the intensity of the emission. As shown in Fig. 3(a), a maximum intensity of the emission is obtained for each kind of phosphors added with $2 \mathrm{wt} \%, 1 \mathrm{wt} \%, 0.5 \mathrm{wt} \%$ and $1 \mathrm{wt} \%$ of $\mathrm{BaCl}_{2}, \mathrm{H}_{3} \mathrm{BO}_{3}, \mathrm{KF}$, and $\mathrm{NH}_{4} \mathrm{~F}$ fluxes, respectively. Therefore, a proper flux adding amount used in the synthesizing sample can obtain an optimal emission intensity of the phosphor.

Fig. 3(b) shows the excitation and emission spectra of the $\mathrm{Ba}_{3} \mathrm{Si}_{6} \mathrm{O}_{12} \mathrm{~N}_{2}: \mathrm{Eu}^{2+}$ phosphors prepared with various kinds of flux. It shows a great similar shape of the spectra except for the PL intensity, which resulted from the same dominant phase of $\mathrm{Ba}_{3} \mathrm{Si}_{6} \mathrm{O}_{12} \mathrm{~N}_{2}$. The excitation spectra of the $\mathrm{Ba}_{3} \mathrm{Si}_{6} \mathrm{O}_{12} \mathrm{~N}_{2}$ : $\mathrm{Eu}^{2+}$ phosphors show a typical broad absorption band from near-UV to blue region (280-500 nm), consisting of two bands with maxima at 313 and $428 \mathrm{~nm}$. The emission spectra exhibit a single broad band centered at $527 \mathrm{~nm}$ under the $428 \mathrm{~nm}$ excitation, which is attributed to the typical $4 \mathrm{f}^{6} 5 \mathrm{~d} \rightarrow 4 \mathrm{f}^{7}$ transition of the $\mathrm{Eu}^{2+}$ ions. The emission intensity of the sample with the various fluxes is founded in the following order: $\mathrm{H}_{3} \mathrm{BO}_{3}(1 \mathrm{wt} \%)>\mathrm{KF}$ $(0.5 \mathrm{wt} \%)>\mathrm{BaCl}_{2}(2 \mathrm{wt} \%)>$ no flux $>\mathrm{NH}_{4} \mathrm{~F}(1 \mathrm{wt} \%)$.

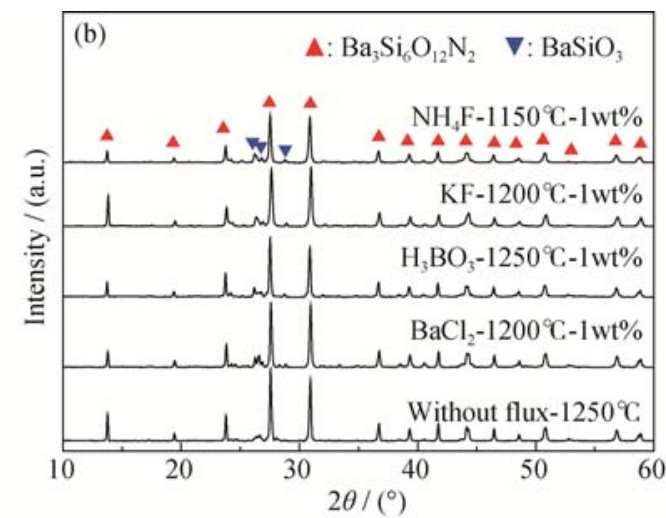

Fig. 1 Photoluminescence intensity (a) of the $\mathrm{Ba}_{3} \mathrm{Si}_{6} \mathrm{O}_{12} \mathrm{~N}_{2}: \mathrm{Eu}^{2+}$ phosphor sintered without flux and with $1 \mathrm{wt} \%$ flux as a function of the calcination temperature $\left(\lambda_{\mathrm{ex}}=428 \mathrm{~nm}\right)$ and XRD patterns $(\mathrm{b})$ of the $\mathrm{Ba}_{3} \mathrm{Si}_{6} \mathrm{O}_{12} \mathrm{~N}_{2}$ : $\mathrm{Eu}^{2+}$ phosphor sintered at various temperatures without flux and with $1 \mathrm{wt} \%$ flux 

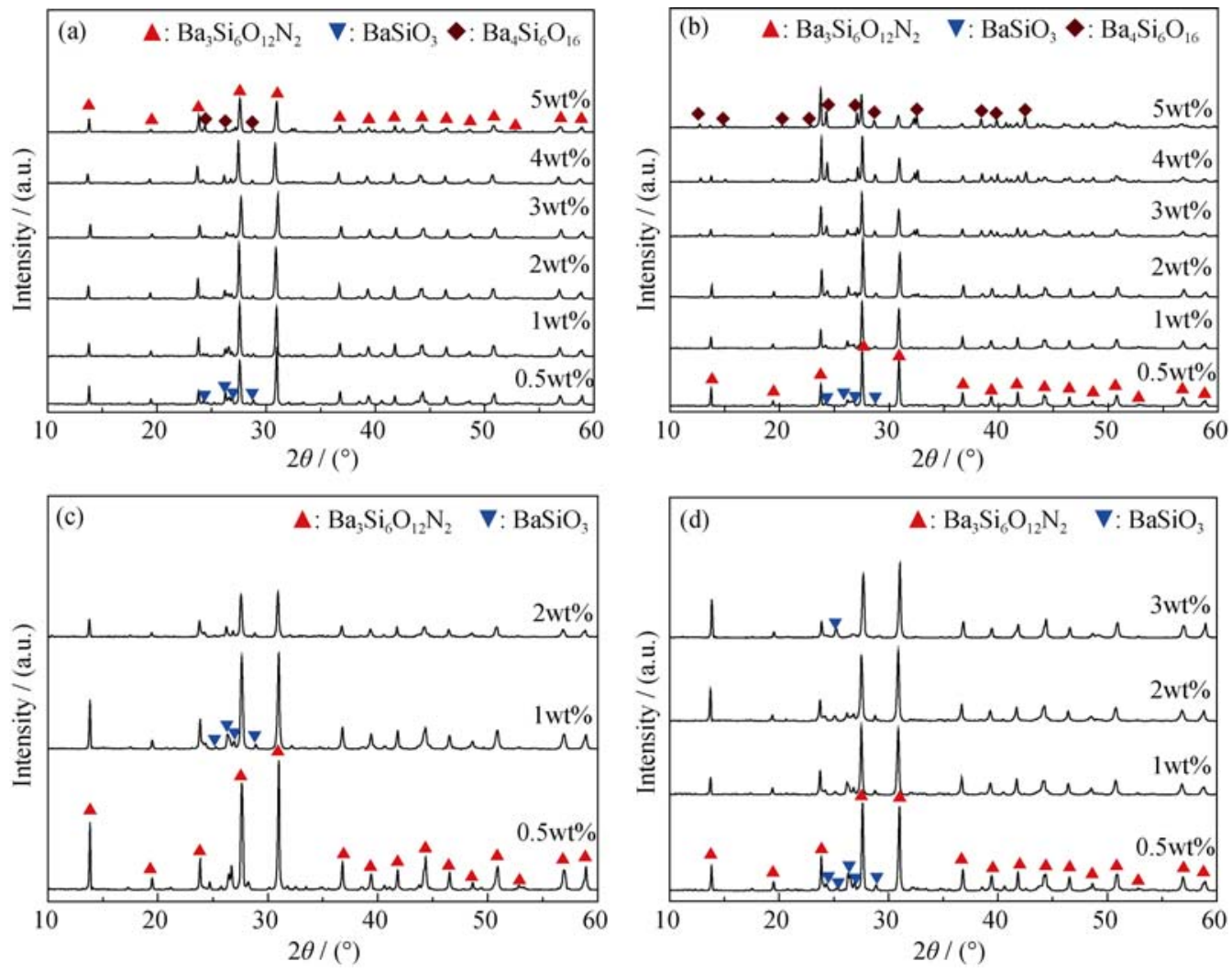

Fig. 2 XRD patterns of the $\mathrm{Ba}_{3} \mathrm{Si}_{6} \mathrm{O}_{12} \mathrm{~N}_{2}$ : $\mathrm{Eu}^{2+}$ phosphor adding various amounts flux (a) $\mathrm{BaCl}_{2}\left(1200^{\circ} \mathrm{C}\right)$; (b) $\mathrm{H}_{3} \mathrm{BO}_{3}\left(1250^{\circ} \mathrm{C}\right)$; (c) $\mathrm{KF}\left(1200^{\circ} \mathrm{C}\right)$; (d) $\mathrm{NH}_{4} \mathrm{~F}\left(1150^{\circ} \mathrm{C}\right)$
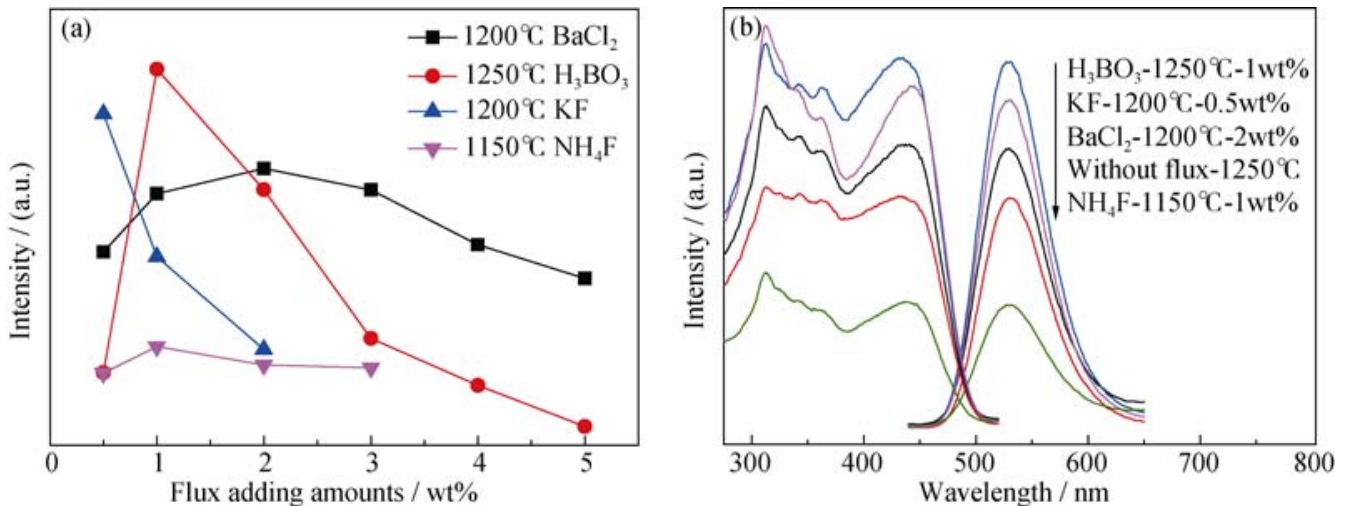

Fig. 3 Effects of flux adding amounts on the emission intensity (a) of the $\mathrm{Ba}_{3} \mathrm{Si}_{6} \mathrm{O}_{12} \mathrm{~N}_{2}$ : Eu ${ }^{2+}$ phosphor and excitation and emission spectra (b) of the $\mathrm{Ba}_{3} \mathrm{Si}_{6} \mathrm{O}_{12} \mathrm{~N}_{2}: \mathrm{Eu}^{2+}$ phosphors $\lambda_{\mathrm{ex}}=428 \mathrm{~nm} ; \lambda_{\mathrm{em}}=527 \mathrm{~nm}$

\subsection{Particle size distribution and SEM observation}

Figure 4 shows the particle size distribution of the $\mathrm{Ba}_{3} \mathrm{Si}_{6} \mathrm{O}_{12} \mathrm{~N}_{2}: \mathrm{Eu}^{2+}$ phosphor with various kinds of fluxes. The particle size of the synthesized sample without flux is $\sim 3.64 \mu \mathrm{m}$ (D50), whereas the particle sizes of the samples with $\mathrm{BaCl}_{2}, \mathrm{H}_{3} \mathrm{BO}_{3}, \mathrm{KF}$ and $\mathrm{NH}_{4} \mathrm{~F}$ are $\sim 6.71$, $4.87, \sim 14.24$ and $\sim 15.06 \mu \mathrm{m}$ (D50), respectively. We may safely draw the conclusion that the addition of a flux can help to facilitate the particle growth, and improve the narrow particle-size distribution. Moreover, high crystallinity could reduce the defects in the lattice and on the surface of the phosphor, it makes sense the enhancement of emission intensity.

Furthermore, the typical scanning electron microscopy images of all the samples are shown in Fig. 5(a)-(e), the surface morphologies indicate a better grain growth with shape anisotropy and less aggregation after introducing the fluxes of $\mathrm{BaCl}_{2}, \mathrm{H}_{3} \mathrm{BO}_{3}$, and $\mathrm{KF}$ except for $\mathrm{NH}_{4} \mathrm{~F}$. The $\mathrm{NH}_{4} \mathrm{~F}$ can have a twofold role in determining the crystallization. Firstly, $\mathrm{NH}_{4} \mathrm{~F}$ is easy to be decomposed into $\mathrm{NH}_{3}$ and HF during the high temperature process, then it could reduce the contact degree of raw materials in the process 
of releasing, which exhibits a hard aggregation and shows an obtuse boundary (indicating poor crystallization) (Fig. 5(e)), lead to the lowest PL intensity. Secondly, during the sintering process of silicon oxide powder with $\mathrm{NH}_{4} \mathrm{~F}$ as additives in the $\mathrm{H}_{2} / \mathrm{N}_{2}$ atmosphere, the following reactions may exist in the low temperature $\left(<1000^{\circ} \mathrm{C}\right)^{[25]}$ :

$$
\begin{gathered}
\mathrm{NH}_{4} \mathrm{~F} \rightarrow \mathrm{NH}_{3}+\mathrm{HF} \\
\mathrm{SiO}_{2}+4 \mathrm{HF} \rightarrow \mathrm{SiF}_{4}+2 \mathrm{H}_{2} \mathrm{O} \\
\mathrm{SiF}_{4}+2 \mathrm{NH}_{3} \rightarrow \mathrm{Si}(\mathrm{NH})_{2}+4 \mathrm{HF} \\
3 \mathrm{Si}(\mathrm{NH})_{2} \rightarrow \mathrm{Si}_{3} \mathrm{~N}_{4} \text { (amoph) }+2 \mathrm{NH}_{3}
\end{gathered}
$$

That is to say, $\mathrm{NH}_{4} \mathrm{~F}$ may act as a catalyst on the nitridation of silicon by the consumption of silicon oxide. According to the paper ${ }^{[10]}$, one can suppose that the phase formation of the $\mathrm{Ba}_{2.8} \mathrm{Si}_{6} \mathrm{O}_{12} \mathrm{~N}_{2}: 0.2 \mathrm{Eu}^{2+}$ samples could be composed of three sequential processes: Firstly, the low-melting point barium orthosilicates emerge when the temperature is up to above $1000^{\circ} \mathrm{C}$; Secondly, silicon nitride starts to dissolve in the Ba-Si-O liquid phase when the temperature further rises to $1200-1300^{\circ} \mathrm{C}$; Thirdly, the target phase then precipitates from the nitrogen saturated liquid phase. As a result, the secondary reactions (1)-(4) mentioned above were unfavorable to form Ba-Si-O liquid phase and ultimately affect the crystallization of the product (Fig. 1(b)). For KF acting as flux, it is likely to generate aggregation in Fig. 5(d). For $\mathrm{BaCl}_{2}$ acting as flux, as displayed in Fig. 5(b), this might be due to the surface segregation of barium. The surface segregation results from the surface energy and strain in the matrix, and atoms with larger radii are more likely to segregate to release the matrix strain in the host lattice. The radius of $\mathrm{Ba}^{2+}$ ion is larger than that of $\mathrm{Eu}^{2+}$, thus $\mathrm{Ba}^{2+}$ could segregate to the phosphor surface. It is to be noted that the amount of europium increases at the surface with a decrease in barium, which was addressed in the production process of red $\mathrm{K}_{4}\left(\mathrm{WO}_{4}\right)_{2}: \mathrm{Eu}^{3+}$ phosphors with $\mathrm{R}_{2} \mathrm{CO}_{3}$ $(\mathrm{R}=\mathrm{Li}, \mathrm{Na}, \mathrm{K})$ fluxes ${ }^{[26]}$. It has been known that $\mathrm{H}_{3} \mathrm{BO}_{3}$ decomposes into $\mathrm{B}_{2} \mathrm{O}_{3}$ and $\mathrm{H}_{2} \mathrm{O}$ at around $500^{\circ} \mathrm{C}^{[27]}$. The
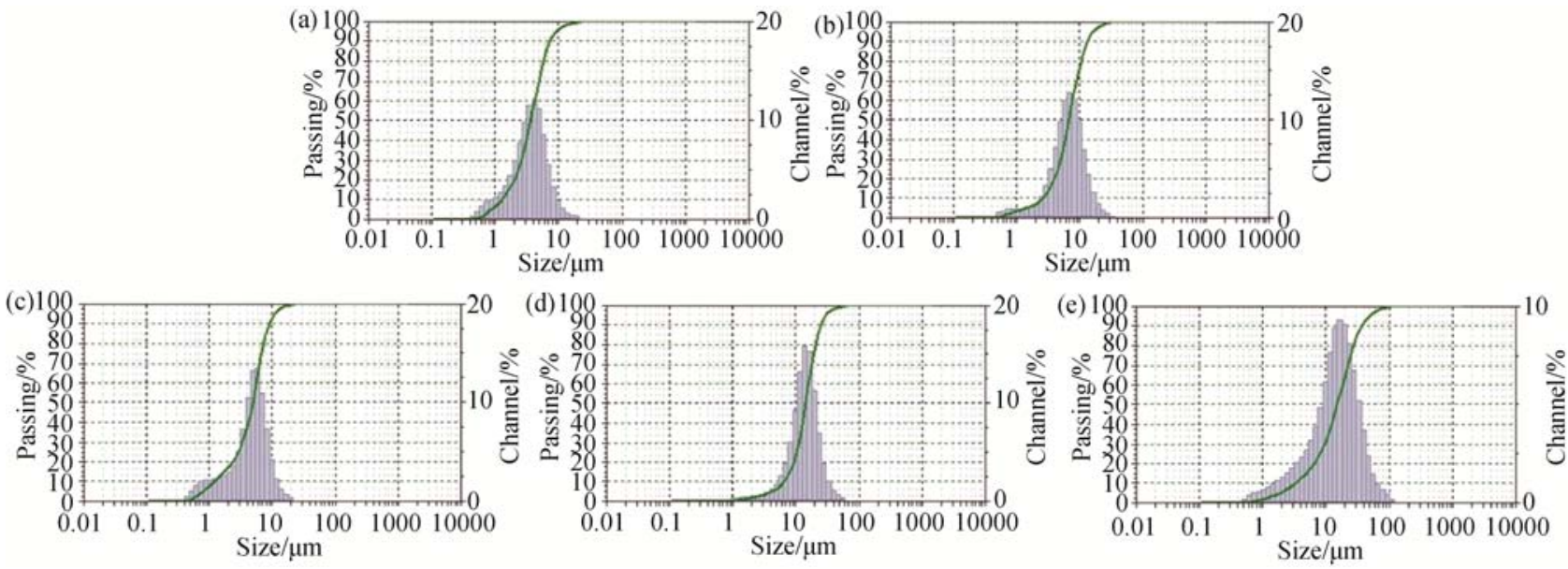

Fig. 4 Particle size distribution of the $\mathrm{Ba}_{3} \mathrm{Si}_{6} \mathrm{O}_{12} \mathrm{~N}_{2}: \mathrm{Eu}^{2+}$ phosphor with various kinds of flux (a) None $\left(1250^{\circ} \mathrm{C}\right)$; (b) $\mathrm{BaCl}_{2}\left(1200^{\circ} \mathrm{C}, 2 \mathrm{wt} \%\right)$; (c) $\mathrm{H}_{3} \mathrm{BO}_{3}\left(1250^{\circ} \mathrm{C}, 1 \mathrm{wt} \%\right)$; (d) $\mathrm{KF}\left(1200^{\circ} \mathrm{C}, 0.5 \mathrm{wt} \%\right)$; (e) $\mathrm{NH}_{4} \mathrm{~F}\left(1150^{\circ} \mathrm{C}, 1 \mathrm{wt} \%\right)$
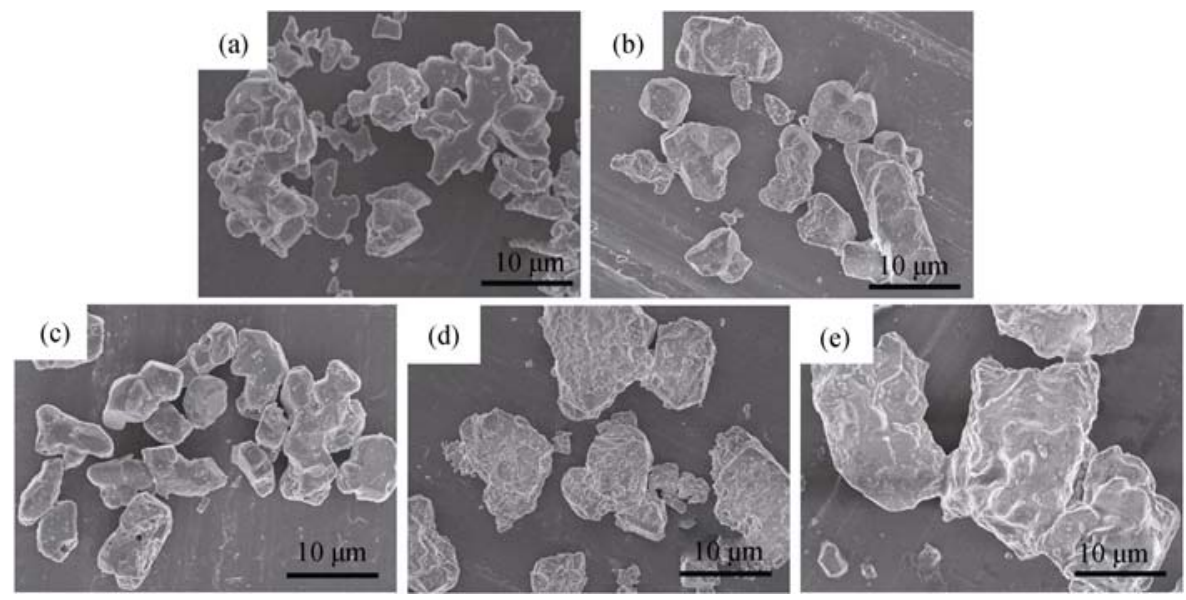

Fig. 5 SEM images of the $\mathrm{Ba}_{3} \mathrm{Si}_{6} \mathrm{O}_{12} \mathrm{~N}_{2}: \mathrm{Eu}^{2+}$ phosphor with various kinds of flux

(a) None $\left(1250^{\circ} \mathrm{C}\right)$; (b) $\mathrm{BaCl}_{2}\left(1200^{\circ} \mathrm{C}, 2 \mathrm{wt} \%\right)$; (c) $\mathrm{H}_{3} \mathrm{BO}_{3}\left(1250^{\circ} \mathrm{C}, 1 \mathrm{wt} \%\right)$; (d) $\mathrm{KF}\left(1200^{\circ} \mathrm{C}, 0.5 \mathrm{wt} \%\right)$; (e) $\mathrm{NH}_{4} \mathrm{~F}\left(1150^{\circ} \mathrm{C}, 1 \mathrm{wt} \%\right)$ 
low melting point of $\mathrm{B}_{2} \mathrm{O}_{3}$ and the low viscosity of melts of boric oxide provide the opportunity for low temperature consolidation of these materials to enter the reaction zone. The premature liquid formed via the melted flux increases the surface tension during the reaction process, making raw materials coagulate together. The presence of $\mathrm{B}_{2} \mathrm{O}_{3}$ seemingly increases the reactivity of $\mathrm{Si}_{3} \mathrm{~N}_{4}$, probably due to dissolution of $\mathrm{Si}_{3} \mathrm{~N}_{4}$ in $\mathrm{B}_{2} \mathrm{O}_{3}{ }^{[28]}$. Meanwhile, phosphors prepared with $\mathrm{H}_{3} \mathrm{BO}_{3}$ shows a smooth surface as can be seen from Fig. 5(c). The above factors make the effect of $\mathrm{H}_{3} \mathrm{BO}_{3}$ flux perform the feat.

\subsection{Quantum efficiency and thermal quenching}

Generally, the fluorescence QE is the probability for a sample to emit a photon through fluorescence when it is excited by a single photon. The external quantum efficiency $\left(\eta_{\text {external }}\right)$ can be calculated by the following equation $(5)^{[10]}$ :

$$
\eta_{\text {external }}=\frac{\int \lambda P(\lambda) \mathrm{d} \lambda}{\int \lambda E(\lambda) \mathrm{d} \lambda}
$$

Where $E(\lambda)$ and $P(\lambda)$ are the intensity per unit wavelength in the spectra of excitation and emission of the phosphor, respectively. Fig. 6 shows the external QE of the $\mathrm{Ba}_{3} \mathrm{Si}_{6} \mathrm{O}_{12} \mathrm{~N}_{2}: \mathrm{Eu}^{2+}$ phosphor with various kinds of fluxes. The external QE of the sample with $1 \mathrm{wt} \% \mathrm{H}_{3} \mathrm{BO}_{3}$ is higher than that of the samples without flux and with other fluxs under 365,405 , or $450 \mathrm{~nm}$ excitation, respectively. The enhanced QE may be due to the increased crystallinity, particle size and smooth surface of the powders, as mentioned above in Fig. 4 and Fig. 5.

The decay curves of $\mathrm{Ba}_{3} \mathrm{Si}_{6} \mathrm{O}_{12} \mathrm{~N}_{2}: \mathrm{Eu}^{2+}$ samples excited at $457 \mathrm{~nm}$ and monitored at $527 \mathrm{~nm}$ are shown in Fig. 7. The decay curve of $\mathrm{Ba}_{3} \mathrm{Si}_{6} \mathrm{O}_{12} \mathrm{~N}_{2}: \mathrm{Eu}^{2+}$ has been analyzed by curve fitting, and it can be well fitted through a single-exponential function. We have obtained a single lifetime $\tau$, which is attributed to the $\mathrm{Eu}^{2+}$ substitution for Ba2-sites in $\mathrm{Ba}_{3} \mathrm{Si}_{6} \mathrm{O}_{12} \mathrm{~N}_{2}{ }^{[9]}$. The values of lifetime were found to be $1.245,1.269,1.275,1.302$, and $1.369 \mu \mathrm{s}$ values for $\mathrm{H}_{3} \mathrm{BO}_{3}, \mathrm{KF}, \mathrm{BaCl}_{2}$, without, and $\mathrm{NH}_{4} \mathrm{~F}$ fluxe- mofdified phosphor, respectively.

Thermal quenching is one of the important technological parameters for phosphors used in W-LEDs. The temperature dependence of the PL spectra of the $\mathrm{Ba}_{3} \mathrm{Si}_{6} \mathrm{O}_{12} \mathrm{~N}_{2}: \mathrm{Eu}^{2+}$ phosphor prepared with $1 \mathrm{wt} \% \mathrm{H}_{3} \mathrm{BO}_{3}$ flux is shown in Fig. 8(a). The inset shows the temperature dependence of the PL intensity for the selected samples. The emission spectrum is blue-shifted as the temperature is raised, which is due to the thermally induced lift up of the lowest $5 \mathrm{~d}$ energy levels. When the phosphor is heated up to $150^{\circ} \mathrm{C}$, the luminescence still remains about $80 \%$ of the initial intensity measured at room temperature. The excellent thermal stability of the $\mathrm{Ba}_{3} \mathrm{Si}_{6} \mathrm{O}_{12} \mathrm{~N}_{2}: \mathrm{Eu}^{2+}$ phosphor can be attributed to the rigid structure caused by the nitrogen coordination and high degree of cross-linking between $\mathrm{SiO}_{3} \mathrm{~N}$ tetrahedral, further may be ascribed to smaller band gap and longer Ba-N distance ${ }^{[9]}$. In addition, the probability of the thermal quenching process is strongly dependent on the energy barrier $\Delta E q$, a greater $\Delta E q$ is correspond to a lower thermal quenching of the phosphor. The activation energy for thermal quenching $\Delta E q$ can be calculated from the Arrhenius equation described by the follow equation $(6)^{[29-30]}$ :

$$
I_{T}=\frac{I_{0}}{1+c \exp \left(-\frac{\Delta E q}{k T}\right)}
$$

Where $I_{0}$ is the initial emission intensity, $I_{\mathrm{T}}$ is the intensity at different temperatures, $\mathrm{C}$ is a constant for a certain host, $\Delta E q$ is the activation energy, $\mathrm{k}$ is the Boltzmann constant $\left(8.629 \times 10^{-5} \mathrm{eV} / \mathrm{K}\right)$, and $T$ is temperature. Fig. $8(\mathrm{~b})$ shows the plots of $-\ln \left[\left(I_{0} / I_{\mathrm{T}}\right)-1\right]$ versus $1 / k T$ for the $\mathrm{Ba}_{3} \mathrm{Si}_{6} \mathrm{O}_{12} \mathrm{~N}_{2}: \mathrm{Eu}^{2+}$ sample mentioned above. The best fit following equation (4) gives the comparable activation energy $\Delta E q$ of $0.243 \mathrm{eV}$ for the $\mathrm{Ba}_{3} \mathrm{Si}_{6} \mathrm{O}_{12} \mathrm{~N}_{2}: \mathrm{Eu}^{2+}$ phosphor with $1 \mathrm{wt} \% \mathrm{H}_{3} \mathrm{BO}_{3}$ flux, which is a little higher than

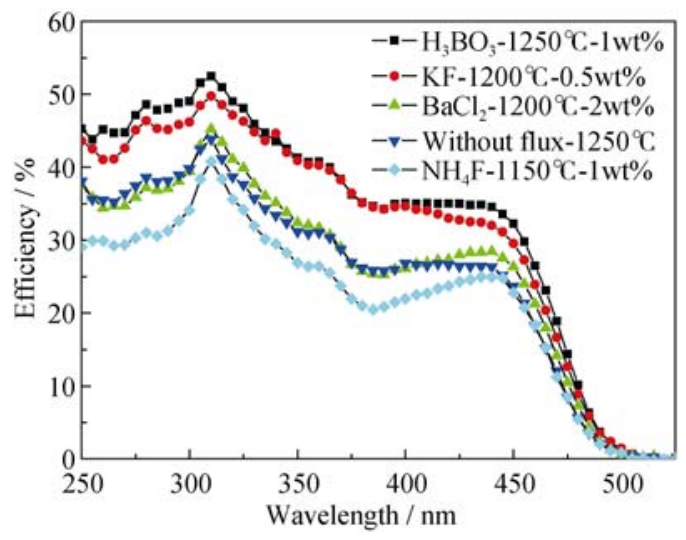

Fig. 6 External quantum efficiencies of the $\mathrm{Ba}_{3} \mathrm{Si}_{6} \mathrm{O}_{12} \mathrm{~N}_{2}: \mathrm{Eu}^{2+}$ phosphor with various kinds of fluxes

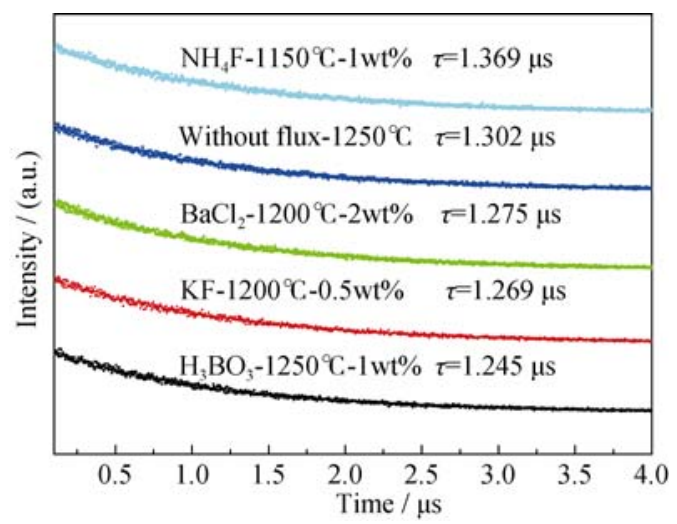

Fig. 7 Fluorescence decay curve of $527 \mathrm{~nm}$ emission for samples prepared with various kinds of fluxes 

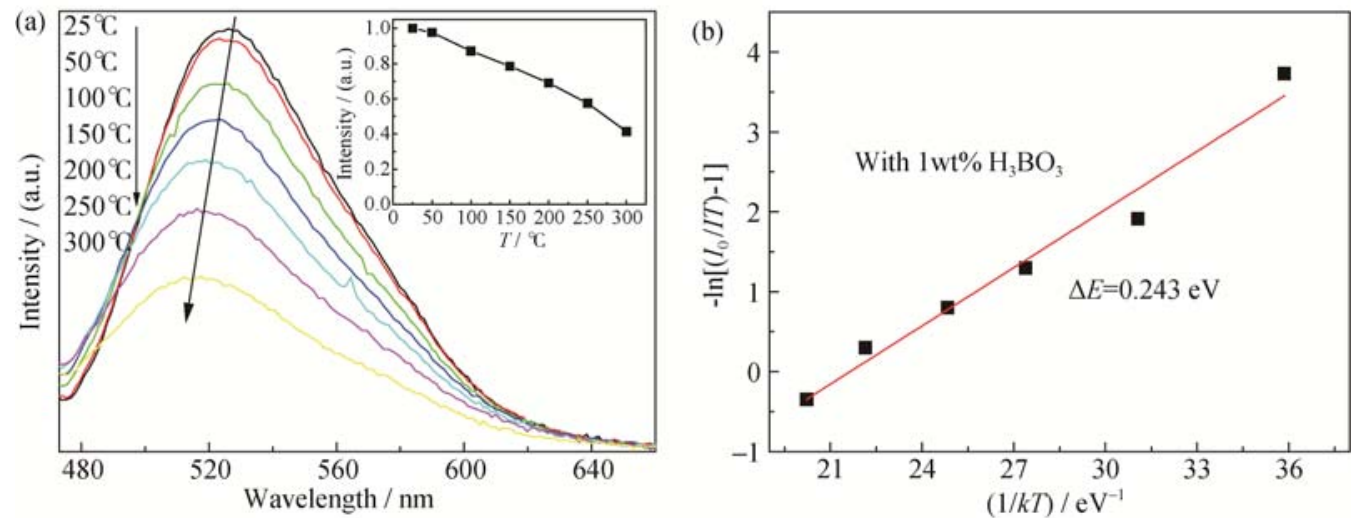

Fig. 8 PL emission spectra (a) as a function of the calcination temperature of the $\mathrm{Ba}_{3} \mathrm{Si}_{6} \mathrm{O}_{12} \mathrm{~N}_{2}: \mathrm{Eu}^{2+}$ phosphor prepared with $1 \mathrm{wt} \%$ $\mathrm{H}_{3} \mathrm{BO}_{3}$ and plots of $-\ln \left[\left(I_{0} / I_{T}\right)-1\right]$ vs $1 / k T$ for the $\mathrm{Ba}_{3} \mathrm{Si}_{6} \mathrm{O}_{12} \mathrm{~N}_{2}: \mathrm{Eu}^{2+}$ sample (b) prepared with $1 \mathrm{wt} \% \mathrm{H}_{3} \mathrm{BO}_{3}$ The inset indicating the emission intensity at varying temperatures of the sample $\left(\lambda_{\mathrm{ex}}=455 \mathrm{~nm}\right)$

the value $(0.20 \mathrm{eV})$ reported in $\mathrm{Sr}_{2} \mathrm{Si}_{5} \mathrm{~N}_{8}: \mathrm{Eu}^{2+}$ phosphor $^{[31]}$, which indicates that phosphor has a better thermal stability. Using the same method, the activation energy $\Delta E q$ for $\mathrm{KF}, \mathrm{BaCl}_{2}$, without, and $\mathrm{NH}_{4} \mathrm{~F}$ fluxemofdified phosphor were foud to be $0.181,0.236,0.170$, and $0.205 \mathrm{eV}$ respectively.

The CIE coordinates of the $\mathrm{Ba}_{3} \mathrm{Si}_{6} \mathrm{O}_{12} \mathrm{~N}_{2}: \mathrm{Eu}^{2+}$ phosphor with $1 \mathrm{wt} \% \mathrm{H}_{3} \mathrm{BO}_{3}$ flux blue-shift from $(0.29,0.62)$ to $(0.27$, 0.56 ) when the temperature rises from $25^{\circ} \mathrm{C}$ to $300^{\circ} \mathrm{C}$ shown in Fig. 9. Bright luminescence of green is generated as shown by the logo of CAS and letters CNITECH under the $365 \mathrm{~nm}$ excitation in the inset of Fig. 9 .

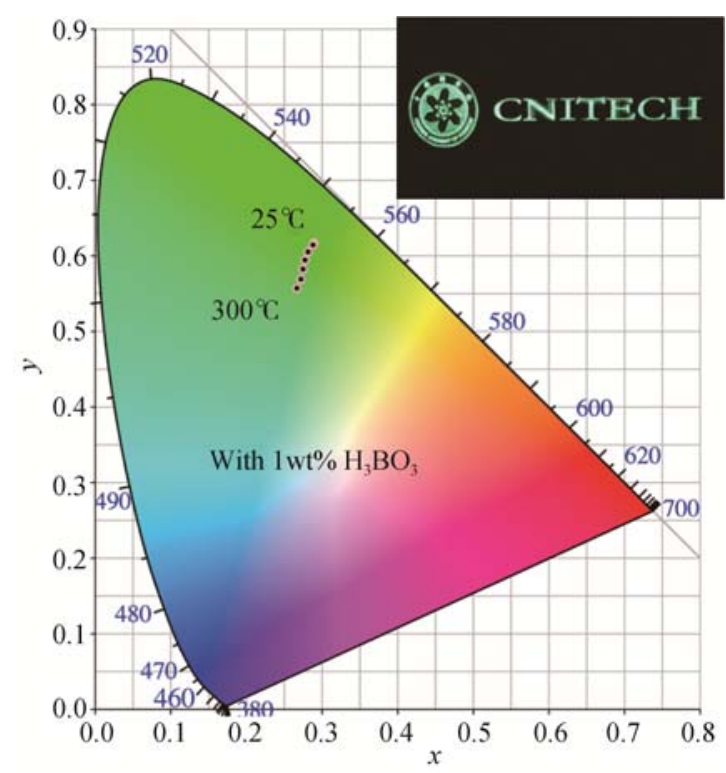

Fig. 9 CIE chromaticity coordinate of the $\mathrm{Ba}_{3} \mathrm{Si}_{6} \mathrm{O}_{12} \mathrm{~N}_{2}: \mathrm{Eu}^{2+}$ phosphor from $25^{\circ} \mathrm{C}$ to $300^{\circ} \mathrm{C}$ calculated by using the emission spectra under $455 \mathrm{~nm}$ excitation.

The inset shows the colorless powder of the $\mathrm{Ba}_{3} \mathrm{Si}_{6} \mathrm{O}_{12} \mathrm{~N}_{2}: \mathrm{Eu}^{2+}$ phosphors which are filled into the logo of CAS and letters CNITECH. The logo and letters display green color under $365 \mathrm{~nm}$ UV light

\section{Conclusions}

We investigated the effect of the $\mathrm{BaCl}_{2}, \mathrm{H}_{3} \mathrm{BO}_{3}, \mathrm{KF}$, and $\mathrm{NH}_{4} \mathrm{~F}$ fluxes on the properties of the green-emitting $\mathrm{Ba}_{3} \mathrm{Si}_{6} \mathrm{O}_{12} \mathrm{~N}_{2}: \mathrm{Eu}^{2+}$ phosphor synthesized by microwave sintering. Fluxes were added to a reaction system, the liquid interfaces were produced among crystal grains, and then the crystal grains reunited and resulted in a bigger particle size. The addition of $\mathrm{H}_{3} \mathrm{BO}_{3}$ flux highly improved the morphology of the $\mathrm{Ba}_{3} \mathrm{Si}_{6} \mathrm{O}_{12} \mathrm{~N}_{2}: \mathrm{Eu}^{2+}$ phosphor sintered at $1250^{\circ} \mathrm{C}$, such as less aggregation, narrower size and shape distributions. Additionally, $\mathrm{B}_{2} \mathrm{O}_{3}$ decomposed from $\mathrm{H}_{3} \mathrm{BO}_{3}$ has a higher reaction activation energy, which could effectively reduce the energy barrier, and then obtain the highest PL intensity for the resultant powders, and the powders showed low thermal quenching, shorter life time and increased external quantum efficiency. The phosphor showed optimal properties when the amount of flux was $1 \mathrm{wt} \% \mathrm{H}_{3} \mathrm{BO}_{3}$. The PL properties showed that all samples could be efficiently excited by blue light $(455 \mathrm{~nm})$, and that they could emit green light $(527 \mathrm{~nm})$, which coupled well with the characteristic emissions blue LEDs.

\section{References:}

[1] DENAULT KRISTIN-A, BRGOCH JAKOAH, GAULTOIS MICHAEL-W, et al. Consequences of optimal bond valence on structural rigidity and improved luminescence properties in $\mathrm{Sr}_{x} \mathrm{Ba}_{2-x} \mathrm{SiO}_{4}: \mathrm{Eu}^{2+}$ orthosilicate phosphors. Chemitry of Materials, 2014, 26(7): 2275-2282.

[2] YE S, XIAO F, PAN Y X, et al. Phosphors in phosphor-converted white light-emitting diodes: recent advances in materials, techniques and properties. Materials Science and Engineering R, 2010, 71: $1-34$.

[3] LIU LI-HONG, XIE RONG-JUN, ZHANG CHEN-NING, et al. 
Role of fluxes in optimizing the optical properties of $\mathrm{Sr}_{0.95} \mathrm{Si}_{2} \mathrm{O}_{2} \mathrm{~N}_{2}: 0.05 \mathrm{Eu}^{2+}$ green-emitting phosphor. Materials, 2013, 6(7): $2862-2872$.

[4] XIE RONG-JUN, HIROSAKI NAOTO, MITOMO MAMORU, et al. Photoluminescence of rare-earth-doped $\mathrm{Ca}-\alpha$-SiAlON phosphors: composition and concentration dependence. Journal of the American Ceramic Society, 2005, 88(10): 2883-2888.

[5] WU QUAN-SHENG, WANG YU-HUA, YANG ZHI-GANG, et al. Synthesis and luminescence properties of pure nitride $\mathrm{Ca}-\alpha$-sialon with the composition $\mathrm{Ca}_{1.4} \mathrm{Al}_{2.8} \mathrm{Si}_{9.2} \mathrm{~N}_{16}$ by gas-pressed sintering. Journal of Materials Chemistry C, 2014, 2(5): 829-834.

[6] HIROSAKI NAOTO, XIE RONG-JUN, KIMOTO KOJI, et al. Characterization and properties of green-emitting beta-SiAlON: $\mathrm{Eu}^{2+}$ powder phosphors for white light-emitting diodes. Applied Physics Letters, 2015, 86(21): 211905-211907.

[7] LI Y Q, VAN STEEN J E J, VAN KREVEL J W H, et al. Luminescence properties of red-emitting $\mathrm{M}_{2} \mathrm{Si}_{5} \mathrm{~N}_{8}: \mathrm{Eu}^{2+}(\mathrm{M}=\mathrm{Ca}, \mathrm{Sr}, \mathrm{Ba})$ LED conversion phosphors. Journal of Alloys and Compounds, 2006, 417(1/2): 273-279.

[8] HU WEI-WEI, CAI CHAO, ZHU QIANG-QIANG, et al. Preparation of high performance $\mathrm{CaAlSiN}_{3}: \mathrm{Eu}^{2+}$ phosphors with the aid of $\mathrm{BaF}_{2}$ flux. Journal of Alloys and Compounds, 2014, 613: 226-231.

[9] MASAYOSHI MIKAMI, SATOSHI SHIMOOKA, KYOTA UHEDA, et al. New green phosphor $\mathrm{Ba}_{3} \mathrm{Si}_{6} \mathrm{O}_{12} \mathrm{~N}_{2}$ :Eu for white LED: crystal structure and optical properties. Key Engineering Materials, 2009, 403: 11-14.

[10] LI WAN-YUAN, XIE RONG-JUN, ZHOU TIAN-LIANG, et al. Synthesis of the phase pure $\mathrm{Ba}_{3} \mathrm{Si}_{6} \mathrm{O}_{12} \mathrm{~N}_{2}: \mathrm{Eu}^{2+}$ green phosphor and its application in high color rendition white LEDs. Dalton Transactions, 2014, 43: 6132-6138.

[11] SONG Y H, KIM B S, JUNG M K, et al. Synthesis and photoluminescence properties of green-emitting $\mathrm{Ba}_{3} \mathrm{Si}_{6} \mathrm{O}_{12} \mathrm{~N}_{2}$ oxynitride phosphor using boron-coated $\mathrm{Eu}_{2} \mathrm{O}_{3}$ for white LED applications. Journal of the Electrochemical Society, 2012, 159(5): J148-J155.

[12] TANG JIA-YE, CHEN JUN-HUA, HAO LU-YUAN, et al. Green $\mathrm{Eu}^{2+}$-doped $\mathrm{Ba}_{3} \mathrm{Si}_{6} \mathrm{O}_{12} \mathrm{~N}_{2}$ phosphor for white light-emitting diodes: synthesis, characterization and theoretical simulation. Journal of Luminescence, 2011, 131: 1101-1106.

[13] BRAUN CORDULA, SEIBALD MARKUS, BÖRGER SASKIA$\mathrm{L}$, et al. Material properties and structural characterization of $\mathrm{M}_{3} \mathrm{Si}_{6} \mathrm{O}_{12} \mathrm{~N}_{2}: \mathrm{Eu}^{2+}$ (M=Ba,Sr)-a comprehensive study on a promising green phosphor for pc-LEDs. Chemistry-A European Journal, 2010, 16(31): 9646-9657.

[14] RYBAKOV KIRILL-I, OLEVSKY EUGENE-A, KRIKUN EKATERINA-V. Microwave sintering: fundamentals and modeling. Journal of American Ceramic Society, 2013, 96(4): 1003-1020.

[15] CHOCKALINGAM SREEKUMAR, EARL DAVID-A. Microwave sintering of $\mathrm{Si}_{3} \mathrm{~N}_{4}$ with $\mathrm{LiYO}_{2}$ and $\mathrm{ZrO}_{2}$ as sintering additives. Materials and Design, 2010, 31(3): 1559-1562.

[16] OGHBAEI MORTEZA, MIRZAEE OMID. microwave versus conventional sintering: a review of fundamentals, advantages and applications. Journal of Alloys and Compounds, 2010, 494(1/2): 175-189.
[17] LIU LI-HONG, ZHOU XIAO-BING, XIE RONG-JUN, et al. Facile synthesis of $\mathrm{Ca}-\alpha-\mathrm{SiAlON}: \mathrm{Eu}^{2+}$ phosphor by the microwave sintering method and its photoluminescence properties. Chinese Science Bulletin, 2013, 58(7): 708-712.

[18] TIEGS T N, KIGGANS J O, KIMREY H D. Microwave sintering of silicon nitride. Ceramic Engineering \& Science Proceedings, 1991, 12(9/10): 1981-1992.

[19] HAN B, WANG Y F, LIU Q, et al. Microwave assisted sintering and photoluminescence properties of $\mathrm{Ba}_{3} \mathrm{Si}_{6} \mathrm{O}_{12} \mathrm{~N}_{2}: \mathrm{Eu}^{2+}$ green phosphors. Journal of Inorganic Materials, 2015, 30(3): 330-336.

[20] ZHANG YUE, LI YA-DONG, YIN YAN-SHENG. Red photoluminescence and morphology of $\mathrm{Eu}^{3+}$ doped $\mathrm{Ca}_{3} \mathrm{La}_{3}\left(\mathrm{BO}_{3}\right)_{5}$ phosphors. Journal of Alloys and Compounds, 2005, 400: 222-226.

[21] SU YAN-KUIN, PENG YI-MING, YANG RU-YUAN, et al. Effects of $\mathrm{NaCl}$ flux on microstructure and luminescent characteristics of $\mathrm{KSrPO}_{4}: \mathrm{Eu}^{2+}$ phosphors. Optical Materials, 2012, 34(9): 1598-1602.

[22] TENG XIAO-MING, ZHUANG WEI-DONG, HU YUN-SHENG, et al. Effect of flux on the properties of $\mathrm{CaAl}_{2} \mathrm{O}_{4}: \mathrm{Eu}^{2+}, \mathrm{Nd}^{3+}$ long afterglow phosphor. Journal of Alloys and Compounds, 2008, 458(1/2): 446-449.

[23] LEE HYUN-JU, KIM KYUNG-PIL, HONG GUN-YOUNG, et al. The effect of flux materials on the physical and optical properties of $\mathrm{Eu}^{3+}$-activated yttrium oxide phosphors. Journal of Luminescence, 2010, 130(6): 941-646.

[24] YU YAN-PING, WANG HAO-HAO, LI LANG-KAI, et al. Effects of various fluxes on the morphology and optical properties of $\mathrm{Lu}_{3-x} \mathrm{Al}_{5} \mathrm{O}_{2}: x \mathrm{Ce}^{3+}$ green phosphors. Ceramics International, 2014, 40(9): 14171-14175.

[25] LI JIN-FU, LI-KANG, LI GUO-BIN, et al. Preparation of $\mathrm{Si}_{3} \mathrm{~N}_{4}$ powder by combustion synthesis. Journal of Ceramic Processing Research, 2009, 10(3): 296-300.

[26] LEE GWAN-HYOUNG, YOON CHULSOO, KANG SHINHOO. Role of flux in the production process of red phosphors for white LEDs. Journal of Materials Science, 2008, 43(18): 6109-6115.

[27] YAN L, FAN Z Y, LU J G, et al. Synthesis of magnesium borate $\left(\mathrm{Mg}_{2} \mathrm{~B}_{2} \mathrm{O}_{5}\right)$ nanowires by chemical vapor deposition method. Chemistry Materials, 2004, 16(13): 2512-2514.

[28] COBLENZ W S, LEWIS D. In situ reaction of $\mathrm{B}_{2} \mathrm{O}_{3}$ with AlN and/or $\mathrm{Si}_{3} \mathrm{~N}_{4}$ to form $\mathrm{BN}$-toughened composites. Journal of the American Ceramic Society, 1988, 71(12): 1080-1085.

[29] HUANG YAN-LIN, NAKAI YOSUKE, TSUBOI TAIJU, et al. The new red-emitting phosphor of oxyfluoride $\mathrm{Ca}_{2} \mathrm{RF}_{4} \mathrm{PO}_{4}: \mathrm{Eu}^{3+}$ $(\mathrm{R}=\mathrm{Gd}, \mathrm{Y})$ for solid state lighting applications. Optics Express, 2011, 19(7): 6303-6311.

[30] ORIVE JOSEBA, BALDA ROLINDES, FERNÁNDEZ JOAQUÍN, et al. Low temperature red luminescence of a fluorinated Mn-doped zinc selenite. Dalton Transactions, 2013, 42(34): 12481-12494.

[31] XIE RONG-JUN, HIROSAKI NAOTO, KIMURA NAOKI, et al. 2-phosphor-converted white light-emitting diodes using oxynitride/nitride phosphors. Applied Physics Letters, 2007, 90(19): 191101-191103. 


\title{
助溶剂对 $\mathrm{Ba}_{3} \mathrm{Si}_{6} \mathrm{O}_{12} \mathrm{~N}_{2}$ : $\mathrm{Eu}^{2+}$ 氮氧化物荧光粉制备 及光学性能的影响
}

\author{
韩 斌 ${ }^{1,2}$, 王义飞 ${ }^{2}$, 刘 茵 $^{3}$, 黄 庆 $^{2}$
}

(1. 上海大学 材料研究所, 上海 200072; 2. 中国科学院 宁波材料技术与工程研究所, 宁波 315201; 3. 中国科学院 上海硅酸盐研究所, 高性能陶瓷和超微结构国家重点实验室, 上海 200050)

\begin{abstract}
摘 要: 采用微波法制备了 $\mathrm{Eu}^{2+}$ 掺杂的 $\mathrm{Ba}_{3} \mathrm{Si}_{6} \mathrm{O}_{12} \mathrm{~N}_{2}$ 绿色氮氧化物荧光粉, 着重研究了不同助熔剂: $\mathrm{BaCl}_{2} 、 \mathrm{H}_{3} \mathrm{BO}_{3} 、 \mathrm{KF}$ 和 $\mathrm{NH}_{4} \mathrm{~F}$ 对 $\mathrm{Ba}_{3} \mathrm{Si}_{6} \mathrm{O}_{12} \mathrm{~N}_{2}$ : $\mathrm{Eu}^{2+}$ 发光性能的影响。利用 $\mathrm{X}$ 射线衍射(XRD)、荧光光谱仪、扫描电子显微镜(SEM)和量子 效率 $(\mathrm{QE})$ 等检测方法研究了不同助溶剂的作用机理。研究结果表明: 添加助溶剂能够显著提高苂光粉的发光强度, 添 加不同助溶剂制备苂光粉的发光强度大小依次为 $\mathrm{H}_{3} \mathrm{BO}_{3}>\mathrm{KF}>\mathrm{BaCl}_{2}>$ 无助溶剂 $>\mathrm{NH}_{4} \mathrm{~F}$ 。当添加 $1.0 \mathrm{wt} \%$ 的 $\mathrm{H}_{3} \mathrm{BO} \mathrm{O}_{3}$ 时, 所制备的荧光粉粒径分布比较均匀, 形貌较好, 荧光粉的发光强度最大, 且与不添加助溶剂制备的苂光粉相比, 有较高的量子效率和吸收效率，不同温度下的发射光谱表明其热淬灭性低，苂光寿命较短。
\end{abstract}

关 键 词: 氮氧化物荧光粉; 助溶剂; 微波烧结技术; 量子效率

中图分类号: TQ174

文献标识码: A 